\title{
Temperature-dependent development and survival of immature stages of the alfalfa leafcutter bee, Megachile rotundata (Hymenoptera: Megachilidae)
}

\author{
GH Whitfield *, KW Richards \\ Agriculture Canada Research Station, Lethbridge, Alberta T1J 4B1, Canada
}

(Received 8 March 1991; accepted 26 September 1991)

\begin{abstract}
Summary - Survival and development of eggs and larvae of the alfalfa leafcutter bee, Megachile rotundata, were determined for 9 constant temperatures ranging from $15-35^{\circ} \mathrm{C}$. Stage-specific survival of immatures was greatest at temperatures of $20-30{ }^{\circ} \mathrm{C}(>75 \%)$ and high temperatures of 32 and $35^{\circ} \mathrm{C}$ caused no greater mortality compared with that of $23-28{ }^{\circ} \mathrm{C}$. When estimates of survival were combined over all stages (egg to prepupal formation) high mortality of 98.6 and $73.3 \%$ was calculated for low constant temperatures of 15 and $18{ }^{\circ} \mathrm{C}$. At all other temperatures, combined survival for immature stages was high ( $>70 \%$ ). Completion of development was observed at all constant temperatures for the egg and 4 instar stages. Rate of development increased with increased temperature from 15 to $35^{\circ} \mathrm{C}$ for the egg and first instar stages whereas for second, third and fourth instars, rate of development generally increased from 15 to $30^{\circ} \mathrm{C}$ and then decreased from 32 to $35^{\circ} \mathrm{C}$. Frequency distributions of development times were constructed for each larval stage. A Weibull function provided a good fit to a single, temperature-independent distribution of normalized development times. Linear regression of development rate versus temperature provided an average base temperature of $15^{\circ} \mathrm{C}$ and 116 degree-days to complete immature stage development.
\end{abstract}

Megachile rotundata / development / mortality / temperature

\section{INTRODUCTION}

The alfalfa leafcutter bee, Megachile rotundata (Fabricius), is the most important pollinator of alfalfa, Medicago sativa $\mathrm{L}$, in the northwestern United States and Canada. The bee is extensively managed to assure that sufficient numbers of adults are available in commercial seed alfalfa fields during flowering. Female bees construct cells of leaf pieces in small-diameter tun- nels and provision the cells with nectar and pollen. Eggs are laid individually in each cell, the egg usually floating on a surface layer of nectar. The cell is capped and then the next cell is constructed so that a time series of progeny-containing cells occupies each tunnel (Richards, 1984).

Information on rate of development and survival of the various life stages of the alfalfa leafcutter bee can be useful in ex-

\footnotetext{
* Correspondence and present address: Agriculture Canada Research Station, Harrow, Ontario, NOR 1G0, Canada.
} 
plaining changes in population increase of the bee in the field during the summer season. Although there are many reports that include empirical information on larval development of the alfalfa leafcutter bee at room temperature, to our knowledge there have been no quantitative studies designed to examine the effect of a wide range of temperatures on stage-specific development and survival. We studied the effect of temperature on emergence and survival of alfalfa leafcutter bees during and after incubation of prepupae (Richards et al, 1987). Undurraga (1978) carried out a comprehensive study of the effect of temperature extremes on development and survival of the immature stages of the alfalfa leafcutter bee. In the majority of his experiments he exposed different life stages to brief periods of high temperatures to determine detrimental effects of larval exposure to high daily temperatures in field shelters. Although temperature thresholds for development were not determined, he reported that survival of larvae was reduced at temperatures lower than $21^{\circ} \mathrm{C}$, and that temperatures over $40^{\circ} \mathrm{C}$ resulted in increased egg and larval mortality. Tepedino and Parker (1986) reared immature stages of the alfalfa leafcutter bee at 4 temperature regimes and reported on the effects of temperature on mortality, diapause and size of adults. These data suggested that immature bees should not be reared at low temperatures because this results in a greater proportion of smaller bees. Larger bees are more desirable for greater fecundity and pollination efficiency. Tasei and Masure (1978) reported that French and Canadian strains of the alfalfa leafcutter bee have similar development rates: $18-19$ days at $22{ }^{\circ} \mathrm{C}$ and $10-11$ days at $29^{\circ} \mathrm{C}$ for egg to adult development. They reported that a temperature of $15^{\circ} \mathrm{C}$ was lethal to eggs and young larvae.
We have been studying the population dynamics of $M$ rotundata for the purpose of constructing simulation models and improving alfalfa leafcutter bee management. In this paper we present information on temperature-dependent survival and development for immature stages of the alfalfa leafcutter bee. The fit of the data to a standard distribution of development times was determined.

\section{MATERIALS AND METHODS}

\section{Laboratory experiments}

Alfalfa leafcutter bee hives consisting of laminated pinewood boards (Richards, 1984) were placed in 4 shelters in an alfalfa field at the Agriculture Canada Research Station, Lethbridge, Alberta in early summer of 1985 . Trays containing prepupae of the alfalfa leafcutter bee were removed from an incubation room that had been maintained at $30^{\circ} \mathrm{C}$ for $\mathrm{Ca} 3$ weeks and placed under the roof of the shelters. Adult alfalfa leafcutter bees completed emergence over a 5-day period and colonized the hives provided.

To determine larval development and survival, 3 hives were randomly selected and returned to the laboratory. The boards were carefully separated by hand and intact alfalfa leafcutter bee cells were retained for examination. The leaf pieces forming caps of cells were removed with a scalpel and cells containing a viable egg (fully formed, shiny in appearance and floating on a layer of nectar) were placed individually, upright, in cell wells of tissue culture plates. The plates were covered and placed in temperature-controlled environmental chambers at constant temperatures $\left( \pm 0.5^{\circ} \mathrm{C}\right)$ of 15,18 , $20,23,25,28,30,32$ and $35^{\circ} \mathrm{C}$. The chambers were set at $70 \% \mathrm{RH}$ and a photoperiod of L:D $16: 8 \mathrm{~h}$. Cells were inspected daily to record lifestage development and mortality. Although bee larvae generaily have 5 instars, the first instar can occur inside the egg, making it difficult to observe. As a result, the morphometric key of Whitfield et al (1987) was used for discrimination among the 4 visible instars. The experiment was repeated every 3 days for 6 weeks by set- 
ting up plates of 10-96 egg-containing cells per temperature treatment. Plates of ceils from different sampling periods (10-15 sampling periods) were treated as replicates in the analysis of results.

To determine survival and development of the eggs of the alfalfa leafcutter bee, eggs of known age were collected. Twenty sections of hive, consisting of 5 boards (52 tunnels), were randomly selected and removed from the same hives described previously. All cells were removed and discarded. The sections were labelled accordingly and replaced in the hives the same day. Within 20 hours the same sections were again removed from the hives and all intact cells were retained. The leaf piece caps of the cells were removed and cells containing a viable egg (less than 24 hours old) were placed in cell wells of tissue culture plates. Hatch and survival of eggs were recorded for various constant temperatures as previously described in the larval development study. Replicate plates of cells were established at each constant temperature by repeated collection of newly laid eggs over a 3-week period.

\section{Analysis of the data}

Percent survival was analyzed by analysis of covariance with developmental stage (egg to 4th instar) as the classification variable. Temperature was used as the continuous factor with both linear and quadratic components.

The number of days to complete development (residence time) for each immature stage was determined for each replicate of cells and assembled into frequency distributions for the given temperatures. The procedure of Wagner et al (1984a) was used to construct cumulative probability distributions and to fit a 3 parameter cumulative Weibull function to a single distribution of all the normalized development times for each instar. This method for providing a mathematical solution for handling probability functions under variable temperature regimes is based on the concepts of Sharpe et al (1977) and Curry et al (1978a, b). Frequency data were entered into a SAS program (Helwig and Council, 1979) and a cumulative frequency distribution was constructed by adding up the frequency of residence times for each constant temperature. The program used the cumulative distribution to provide estimates of median development time through linear interpolation. For each instar, the program calculated the development times at $1,5,10, \ldots, 95,99$ and $100 \%$ of each cumulative distribution and divided the resulting 22 residence times by the median time (time at 50\%) for each temperature-dependent distribution. This resulted in a cumulative distribution of normalized development times for each constant temperature referred to as tau distributions (Wagner et al, 1984a). A standard temperature-dependent (tau) distribution was calculated by weighting the individual tau values for each distribution by the frequency or number of individuals that successfully completed development to the next instar. A cumulative Weibull function was fitted by the program to the 22 standard tau values where the function has the form:

$$
\left.F(x)=1-\exp (-[x-\gamma) / \eta]^{\beta}\right)
$$

where $F(x)$ is the probability of emergence at normalized time $x$, and eta $(\eta)$, beta $(\beta)$ and gamma $(\gamma)$ are estimated parameters.

The reciprocals of the median residence times (days) for completion of development at each temperature were expressed as a percentage development per day. Threshold temperature for development of each stage was estimated by linear regression (Arnold, 1959). Leastsquares regression analysis was performed on the linear portion of the development data for eggs and first, second, third and fourth instar to determine the base temperature ( $x$-intercept) when development $(y)$ was equal to zero. The number of degree-days above the lower base temperature required for completion of development was determined by taking the reciprocal of the slope of the linear regression line (Campbell et al, 1974).

\section{RESULTS AND DISCUSSION}

\section{Stage-specific survival}

Removal of the 2 or 3 leaf pieces forming the cell caps to facilitate examination of the immature stages did not adversely affect survival or development. Covered cell 
walls of tissue culture plates used to hold alfalfa leafcutter bee cells protected the developing immature stages from desiccation even at $30^{\circ} \mathrm{C}$ and above. A proportion of eggs and larvae survived and developed to the prepupal stage at all constant temperatures tested (table 1). Analysis of covariance revealed mean percent survival was affected by temperature in the intercept, linear and quadratic components and that the relationship varied across stages of development $\left(P=0.001, \mathrm{MSE}_{\mathrm{df}}\right.$ $=451$ ). Survival of egg and larval stages was lower at 15 and $18^{\circ} \mathrm{C}$ with the exception of the egg stage at $18{ }^{\circ} \mathrm{C}$. When survival for all stages was combined (egg to prepupae formation), reduced survival at low temperatures was more evident, with just over $1 \%$ of the immature stages surviving at a constant temperature of $15^{\circ} \mathrm{C}$. Although survival was consistently greatest at temperatures of 20 to $30^{\circ} \mathrm{C}$, high temperatures of 32 and $35{ }^{\circ} \mathrm{C}$ did not cause greater mortality of individual stages. Only when survival was combined over all stages did greater mortality occur at temperatures of 30 or over compared with temperatures of $23-28^{\circ} \mathrm{C}$.
Our results on survival of immatures at various constant temperatures agree with the results of Tepedino and Parker (1986), who reported that significantly greater preoverwintering mortality of immature $\mathrm{M}$ rotundata occurred at the low-temperature treatment of $16^{\circ} \mathrm{C}$ than at all other temperature treatments $\left(24,29,29: 16{ }^{\circ} \mathrm{C}(12 \mathrm{~h}: 12\right.$ h). Similarly, they reported mortality of $>$ $80 \%$ when immature bees were reared at $16^{\circ} \mathrm{C}$. Bitner (1976) and Tasei and Masure (1978) also reported very high immature mortality at temperatures of 14 to $15^{\circ} \mathrm{C}$. At temperatures of 28 and $30{ }^{\circ} \mathrm{C}$, we observed combined stage mortality (egg to prepupae formation) of only 11.5 and $14.6 \%$, respectively. These results agree with those of Undurraga (1978), who reported that although larval development can proceed at temperatures $<21^{\circ} \mathrm{C}$, survival is reduced and that when eggs and young larvae were reared at a constant temperature of $30{ }^{\circ} \mathrm{C}$, over $85 \%$ survival was observed. In southern Alberta, Canada, mean monthly temperatures during normal immature development of $M$ rotundata are $14.9{ }^{\circ} \mathrm{C}$ for June, $18.1^{\circ} \mathrm{C}$ for July and $17.0^{\circ} \mathrm{C}$ for August (88-year average

Table I. Mean survival of the egg and larval stages of Megachile rotundata at various constant temperatures.

\begin{tabular}{|c|c|c|c|c|c|c|}
\hline \multirow{2}{*}{$\begin{array}{l}\text { Temp } \\
\left({ }^{\circ} \mathrm{C}\right)\end{array}$} & \multicolumn{5}{|c|}{ Mean percentage survival ( \pm SE) } & \multirow{2}{*}{$\begin{array}{c}\text { Combined } \\
\text { stages }\end{array}$} \\
\hline & Egg & 1 st instar & 2nd instar & 3rd instar & 4th instar & \\
\hline 15 & $25.6 \pm 6.9$ & $61.0 \pm 3.5$ & $19.5 \pm 3.6$ & $29.5 \pm 7.1$ & $18.3 \pm 8.8$ & $1.4 \pm 0.7$ \\
\hline 18 & $55.5 \pm 13.1$ & $89.6 \pm 1.9$ & $73.2 \pm 3.1$ & $62.5 \pm 3.8$ & $74.6 \pm 3.4$ & $26.7 \pm 2.3$ \\
\hline 20 & $85.9 \pm 5.5$ & $96.8 \pm 1.0$ & $97.6 \pm 0.6$ & $93.2 \pm 1.0$ & $97.9 \pm 0.5$ & $81.1 \pm 1.7$ \\
\hline 23 & $77.5 \pm 3.7$ & $99.8 \pm 0.2$ & $99.1 \pm 0.3$ & $97.1 \pm 0.7$ & $98.9 \pm 0.5$ & $88.2 \pm 1.8$ \\
\hline 25 & $90.1 \pm 3.5$ & $97.7 \pm 0.4$ & $99.6 \pm 0.2$ & $99.4 \pm 0.3$ & $98.9 \pm 0.4$ & $91.0 \pm 0.9$ \\
\hline 28 & $89.6 \pm 4.0$ & $98.6 \pm 0.4$ & $98.4 \pm 0.4$ & $98.9 \pm 0.4$ & $98.7 \pm 0.6$ & $88.5 \pm 1.1$ \\
\hline 30 & $89.0 \pm 2.9$ & $98.4 \pm 0.6$ & $98.3 \pm 0.5$ & $98.5 \pm 0.6$ & $97.1 \pm 0.6$ & $85.4 \pm 2.1$ \\
\hline 32 & $71.4 \pm 6.7$ & $97.7 \pm 0.7$ & $95.7 \pm 0.4$ & $92.1 \pm 1.1$ & $94.8 \pm 0.9$ & $72.7 \pm 1.8$ \\
\hline 35 & $69.6 \pm 3.0$ & $97.7 \pm 0.9$ & $96.5 \pm 1.4$ & $93.8 \pm 2.4$ & $97.1 \pm 1.0$ & $76.8 \pm 4.3$ \\
\hline
\end{tabular}


ompiled at the meteorological station on the Research Station). Low daily temperatures during the summer season do not normally fall below $10^{\circ} \mathrm{C}$. Although cells are often exposed to temperatures $>35$ ${ }^{\circ} \mathrm{C}$, these periods are brief. Thus it appears the immature stages of $M$ rodundata are well adapted to the summer temperatures of southern Alberta, Canada.

\section{Development rates and distribution}

Rate of development increased with increased temperature from 15 to $35^{\circ} \mathrm{C}$ for the egg and first-instar stages, whereas for second, third and fourth instars, rate of development generally increased with temperature from 15 to $30^{\circ} \mathrm{C}$ and then decreased from 32 to $35^{\circ} \mathrm{C}$ (table II). Egg development was considerably slower from 15 to $20{ }^{\circ} \mathrm{C}$ compared to all other temperatures. Time of development from egg hatch to formation of the prepupal stage was $23.5,14.5,11.6$ and 8.3 days at $20,23,25$ and $30{ }^{\circ} \mathrm{C}$, respectively. The proportion of development time for each stage over total immature development time averaged over all constant temperatures was $28 \%$ for eggs, $11 \%$ for first instar, $16 \%$ for second instar, $20 \%$ for third instar and $25 \%$ for fourth instar.

The distribution of residence times for the egg stage was limited to a narrow range at all temperatures (fig 1). Only 2 class intervals were observed for development at $18{ }^{\circ} \mathrm{C}$ and for temperatures of 25 to $35^{\circ} \mathrm{C}$. At $20^{\circ} \mathrm{C}$ all replicates of eggs had the same residence time. As a result, there were insufficient observations to adequately describe the distribution of development for the egg stage and these data were not fitted to a Weibull function. Sampling times of $<12$ hours may be necessary in temperature-dependent development studies to measure and provide distribution data on development of eggs in $M$ rotundata.
Table II. Mean number of days (residence times), standard error and median time of development for the egg and larval stages of Megachile rotundata at various constant temperatures.

\begin{tabular}{|c|c|c|c|c|}
\hline \multirow[t]{2}{*}{ Stage } & \multirow[t]{2}{*}{$\begin{array}{c}\text { Temp } \\
\left({ }^{\circ} \mathrm{C}\right)\end{array}$} & \multirow[t]{2}{*}{$\begin{array}{c}\text { No } \\
\text { of cells }\end{array}$} & \multicolumn{2}{|c|}{$\begin{array}{l}\text { No of days } \\
\text { to } 50 \% \text { completion } \\
\text { of development }\end{array}$} \\
\hline & & & $M e a n \pm S E$ & Median \\
\hline \multirow[t]{9}{*}{ Egg } & 15 & 64 & $16.9 \pm 0.14$ & 16.6 \\
\hline & 18 & 105 & $11.1 \pm 0.05$ & 11.1 \\
\hline & 20 & 165 & $7.0 \pm 0.0$ & 7.0 \\
\hline & 23 & 193 & $3.8 \pm 0.05$ & 3.9 \\
\hline & 25 & 172 & $2.9 \pm 0.04$ & 2.9 \\
\hline & 28 & 141 & $2.3 \pm 0.04$ & 2.4 \\
\hline & 30 & 189 & $2.0 \pm 0.04$ & 2.1 \\
\hline & 32 & 134 & $1.8 \pm 0.04$ & 1.7 \\
\hline & 35 & 226 & $1.6 \pm 0.02$ & 1.6 \\
\hline \multirow[t]{9}{*}{ 1st instar } & 15 & 453 & $4.5 \pm 0.19$ & 3.8 \\
\hline & 18 & 803 & $3.2 \pm 0.08$ & 2.7 \\
\hline & 20 & 799 & $2.8 \pm 0.07$ & 2.3 \\
\hline & 23 & 832 & $1.4 \pm 0.02$ & 1.4 \\
\hline & 25 & 733 & $2.6 \pm 0.06$ & 3.1 \\
\hline & 28 & 881 & $1.7 \pm 0.03$ & 1.8 \\
\hline & 30 & 905 & $1.5 \pm 0.02$ & 1.5 \\
\hline & 32 & 835 & $0.9 \pm 0.02$ & 0.9 \\
\hline & 35 & 1050 & $0.8 \pm 0.01$ & 0.7 \\
\hline \multirow[t]{9}{*}{ 2nd instar } & 15 & 101 & $11.5 \pm 0.59$ & 9.2 \\
\hline & 18 & 593 & $6.5 \pm 0.12$ & 5.7 \\
\hline & 20 & 841 & $3.1 \pm 0.04$ & 2.9 \\
\hline & 23 & 877 & $1.7 \pm 0.03$ & 1.6 \\
\hline & 25 & 868 & $1.3 \pm 0.03$ & 1.1 \\
\hline & 28 & 800 & $1.0 \pm 0.02$ & 0.9 \\
\hline & 30 & 788 & $0.9 \pm 0.02$ & 0.8 \\
\hline & 32 & 765 & $1.1 \pm 0.02$ & 1.0 \\
\hline & 35 & 696 & $1.3 \pm 0.03$ & 1.2 \\
\hline \multirow{9}{*}{ 3rd instar } & 15 & 41 & $13.7 \pm 0.91$ & 13.3 \\
\hline & 18 & 351 & $7.8 \pm 0.22$ & 7.3 \\
\hline & 20 & 778 & $3.7 \pm 0.08$ & 3.4 \\
\hline & 23 & 837 & $2.1 \pm 0.05$ & 1.7 \\
\hline & 25 & 866 & $1.2 \pm 0.03$ & 1.0 \\
\hline & 28 & 797 & $1.1 \pm 0.02$ & 1.1 \\
\hline & 30 & 786 & $1.1 \pm 0.02$ & 1.1 \\
\hline & 32 & 716 & $1.5 \pm 0.03$ & 1.4 \\
\hline & 35 & 919 & $1.3 \pm 0.03$ & 1.2 \\
\hline \multirow[t]{9}{*}{ 4th instar } & 15 & 7 & $5.9 \pm 0.84$ & 5.8 \\
\hline & 18 & 268 & $7.1 \pm 0.18$ & 7.2 \\
\hline & 20 & 756 & $6.9 \pm 0.07$ & 6.9 \\
\hline & 23 & 843 & $5.5 \pm 0.05$ & 5.5 \\
\hline & 25 & 856 & $3.6 \pm 0.05$ & 3.7 \\
\hline & 28 & 833 & $2.9 \pm 0.04$ & 2.9 \\
\hline & 30 & 789 & $2.8 \pm 0.04$ & 2.7 \\
\hline & 32 & 705 & $4.2 \pm 0.07$ & 3.9 \\
\hline & 35 & 924 & $3.2 \pm 0.05$ & 2.9 \\
\hline
\end{tabular}



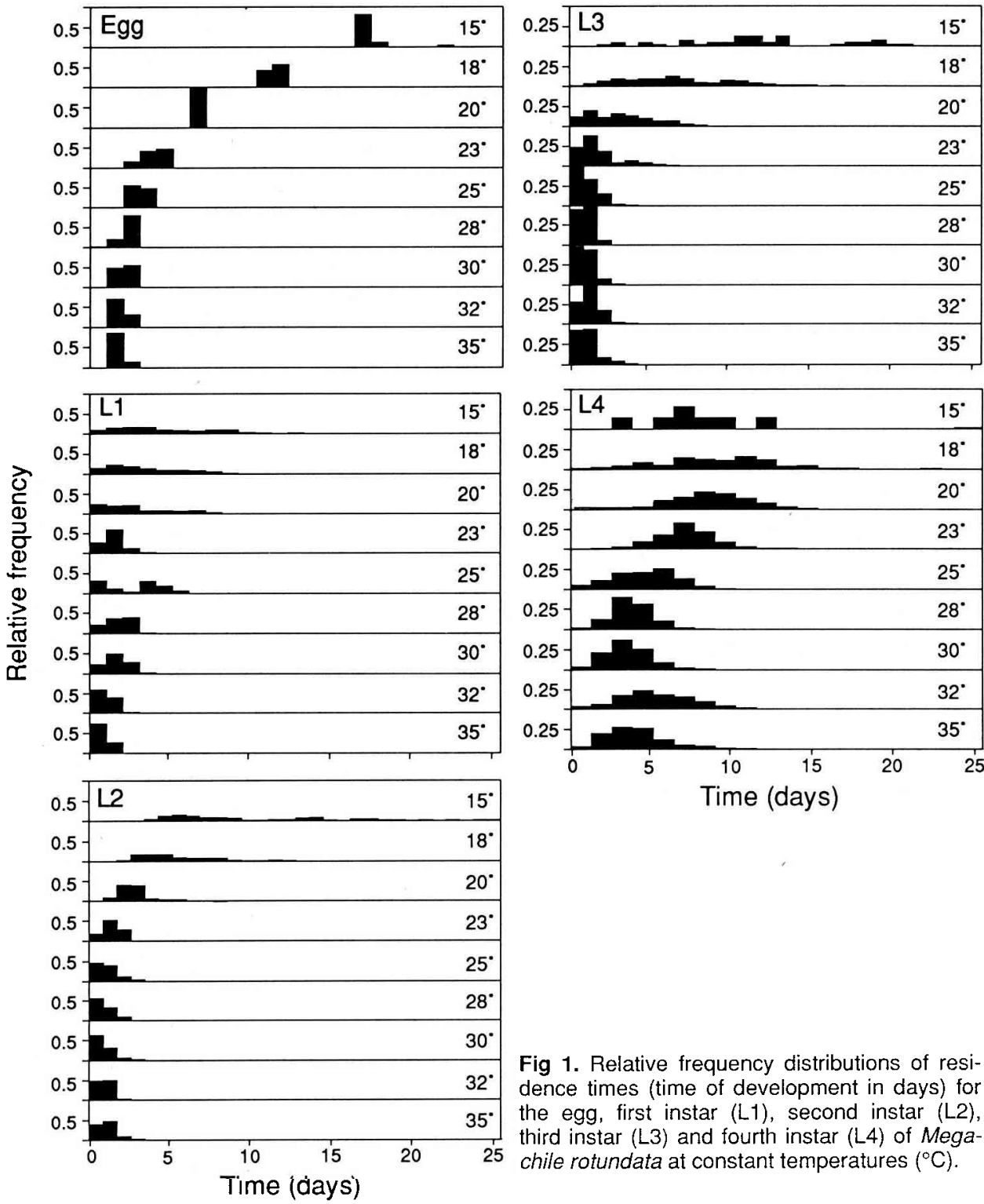

Fig 1. Relative frequency distributions of residence times (time of development in days) for the egg, first instar (L1), second instar (L2), third instar (L3) and fourth instar (L4) of Megachile rotundata at constant temperatures $\left({ }^{\circ} \mathrm{C}\right)$.

The distribution of residence times of larval stages was greatly influenced by temperature (fig 1). At low temperatures of $15-20{ }^{\circ} \mathrm{C}$ there was considerably greater range in relative frequency of residence times for larvae than at all other tempera-

tures. For second and third instars, the distribution was skewed to shorter development times at high temperatures of 25 to $35{ }^{\circ} \mathrm{C}$. The distribution was approximately symmetrical at these same temperatures for the fourth instar; however, there was 
greater variance in development times for fourth instar development at temperatures of $25^{\circ} \mathrm{C}$ or more.

Cumulative distributions of normalized residence times were similar among the various temperatures (fig 2). For all larval stages the distributions overlapped sufficiently at all temperatures to allow for the calculation of single, temperatureindependent distributions. The cumulative Weibull function provided a good description of these standard curves (fig 2). Least-square parameter estimates for the Weibull function are given in table III.

Linear regression of median rate of development and temperature was performed on the linear portions of the temperature-dependent development curve: egg $\left(18-32{ }^{\circ} \mathrm{C}, R^{2}=0.997\right)$, first instar $\left(20-35^{\circ} \mathrm{C}, R^{2}=0.700\right)$, second instar (18$\left.30^{\circ} \mathrm{C}, R^{2}=0.996\right)$, third instar $\left(18-30^{\circ} \mathrm{C}\right.$, $\left.R^{2}=0.921\right)$ and fourth instar $\left(20-30^{\circ} \mathrm{C}\right.$, $R^{2}=0.949$ ). The parameters for the regression equations are given in table III along with the determined base temperatures $\left(T_{b}\right)$ and numbers of degree-days for development $(K)$. A total of 116 degreedays and an average threshold temperature of $15^{\circ} \mathrm{C}$ was necessary to complete development from the egg stage to prepupal formation in $M$ rotundata.

Although there have been many studies on post-overwintering development of prepupae (see review by Richards and Whitfield, 1988), this is the first detailed report on temperature-dependent development for immature stages of $M$ rotundata. There is considerable benefit in predicting pupal development and adult emergence in the spring because time of release of adults must be closely synchronized with time of alfalfa bloom to achieve best pollination results. Similarly, information about immature stage survival and development can be useful when the data are used in population models for predicting mortality, natality and population growth.
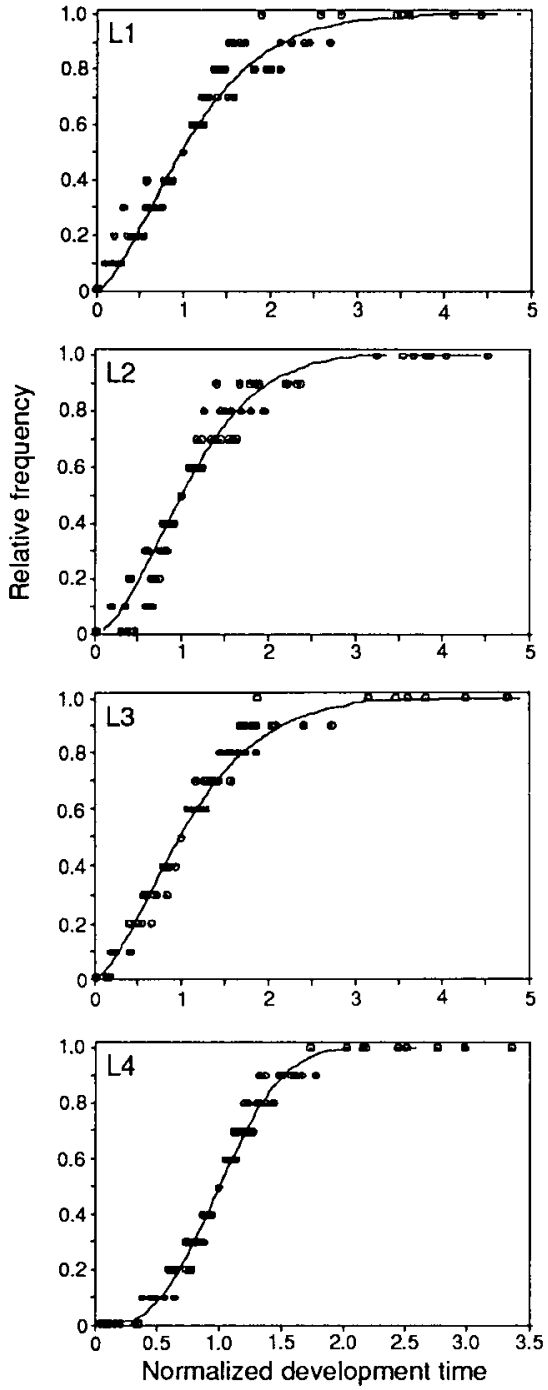

Fig 2. The Weibull function (curve) fitted to the standard normalized mean of the 9 normalized cumulative probability distributions (data points) (residence times at $1,5,10, \ldots 95,99$ and $100 \%$ ) for each of 9 distributions divided by their respective median times) for the first instar (L1), second instar (L2), third instar (L3) and fourth instar (L4) of Megachile rotundata. See equation (1) and table III for parameter values. 
Table III. Parameter estimates for the Weibull function (equation 1) fitted to the standard cumulative distribution of normalized residence times, and the linear regression fitted to development rate versus constant temperature data for immature stages of Megachile rotundata.

\begin{tabular}{|c|c|c|c|c|}
\hline \multirow[t]{2}{*}{ Stage } & \multicolumn{2}{|c|}{ Weibull distribution function } & \multicolumn{2}{|c|}{ Linear regression } \\
\hline & Parameters & Estimates & Parameters & Estimates \\
\hline Egg & $\begin{array}{l}\eta \\
\beta \\
\gamma\end{array}$ & $\begin{array}{l}- \\
-\end{array}$ & $\begin{array}{l}\text { Constant } \\
\text { Slope } \\
\mathrm{a} T_{\mathrm{b}} \\
{ }^{\mathrm{b} K}\end{array}$ & $\begin{array}{c}-0.52492 \\
0.03412 \\
15.4 \pm 0.20 \\
29 \pm 0.4\end{array}$ \\
\hline 1st instar & $\begin{array}{l}\eta \\
\beta \\
\gamma\end{array}$ & $\begin{array}{l}1.23629 \\
1.50501 \\
0\end{array}$ & $\begin{array}{l}\text { Constant } \\
\text { Slope } \\
T_{\mathrm{b}} \\
K\end{array}$ & $\begin{array}{c}-0.8124 \\
0.05572 \\
14.6 \pm 0.31 \\
18 \pm 0.4\end{array}$ \\
\hline 2nd instar & $\begin{array}{l}\eta \\
\beta \\
\gamma\end{array}$ & $\begin{array}{l}1.23296 \\
1.71597 \\
0\end{array}$ & $\begin{array}{l}\text { Constant } \\
\text { Slope } \\
T_{\mathrm{b}} \\
K\end{array}$ & $\begin{array}{c}-1.30098 \\
0.081587 \\
15.9 \pm 0.41 \\
12 \pm 0.23\end{array}$ \\
\hline 3rd instar & $\begin{array}{l}\eta \\
\beta \\
\gamma\end{array}$ & $\begin{array}{l}1.24571 \\
1.50807 \\
0\end{array}$ & $\begin{array}{l}\text { Constant } \\
\text { Slope } \\
T_{\mathrm{b}} \\
K\end{array}$ & $\begin{array}{c}-1.13253 \\
0.07168 \\
15.8 \pm 0.33 \\
14 . \pm 0.3\end{array}$ \\
\hline 4th instar & $\begin{array}{l}\eta \\
\beta \\
\gamma\end{array}$ & $\begin{array}{l}1.07214 \\
2.70979 \\
0.06505\end{array}$ & $\begin{array}{l}\text { Constant } \\
\text { Slope } \\
T_{\mathrm{b}} \\
K\end{array}$ & $\begin{array}{c}-0.32882 \\
0.023418 \\
14.1 \pm 0.19 \\
43 \pm 0.9\end{array}$ \\
\hline
\end{tabular}

${ }^{\mathrm{a}} T_{\mathrm{b}}=$ base temperature for development in ${ }^{\circ} \mathrm{C} \pm \mathrm{SE} .{ }^{\mathrm{b}} \mathrm{K}=$ number of degree days to complete development $\pm \mathrm{SE}$.

Estimates of base temperature and degree-day accumulation for stage-specific development based on linear approximations of mean development rates are useful in determining the phenology of $M$ rotundata in the field. The predictive precision of degree-day models depends upon the temperature range over which development was measured (Messenger, 1959) and also on what resolution is required. For example, while the stagespecific degree-day models presented here may not be very appropriate for pre- diction of initial conditions (ie, $5 \%$ occurrence of first instars), they may be useful for predicting time of average $(50 \%)$ occurrence of larvae. Their greatest asset is in the ease of computation and general acceptance among agricultural extension personnel and growers. A major problem with degree-day models is that they only predict development from mean rate versus constant temperature relationships (see Wagner et al, 1984b). Researchers constructing detailed models of insect population growth have realized the benefits of 
including the inherent variability observed in temperature-development experiments in age-structured models. Insect population models incorporating rate-summation for instar development make use not only of stage-specific, non-linear development curves but also development distribution data to introduce some aspects of stochasticity and realism in simulating actual field results (Carruthers et al, 1986; Régnière, 1984, 1987). The Weibull parameters determined in this study for larval development of $M$ rotundata will be useful for construction of simulation models for leafcutter bee population growth. Schaalje and van der Vaart (1989) did a comprehensive review of variable development rate models and proposed a classification scheme for providing guidance in selection or development of appropriate insect population models. Further studies in our laboratory are planned to develop a high-resolution process model for $M$ rotundata using the Weibull function and non-linear developmental data presented here and estimates of population growth from field sampling.

The temperature-dependent development data and associated development distribution curves presented here are based only on controlled laboratory experiments and are assumed to represent ideal conditions. The utility of only including temperature-dependent functions in predictive phenology models for the alfalfa leafcutter bee is likely limited. More information about the effect of environmental and edaphic factors will be required for incorporation in predictive models if simulation results are to be adequately compared with field observations.

\section{ACKNOWLEDGMENTS}

We thank T Kveder and JF Virostek for technical assistance in the laboratory and $E$ Maw and $S$ Braun for assistance in the preparation of the figures.
Résumé - Étude du développement et de la survie des stades immatures, en fonction de la température, chez la Mégachile Megachile rotundata (Hymenoptera: Megachilidae). La mégachile $\mathrm{Me}$ gachile rodundata (Fabricius) est le pollinisateur le plus important de la luzerne $\mathrm{Me}$ dicago sativa $\mathrm{L}$, dans le Nord-Ouest des États-Unis et au Canada. La dynamique des populations de $M$ rotundata a été étudiée dans le but de construire des modèles de simulation pour la production d'abeilles et la pollinisation de la luzerne (Richards et al, 1987). Dans cet article, sont rapportées des données concernant le taux moyen de développement et la distribution des différents stades de la mégachile. L'adaptation des données à une distribution standard, permettant l'utilisation des temps de développement comme modèles, a été également réalisée.

Au laboratoire, les effets d'une température constante sur le développement et la survie ont été déterminés. Des cellules de couvain de mégachile ont été obtenues à partir de ruches maintenues au champ. L'opercule de la cellule a été enlevé pour faciliter l'examen, et toutes les cellules contenant un œuf viable (d'âge inconnu) ont été conservées. Ces cellules ont été placées dans des puits de plaque de culture de tissus, et maintenues à différentes températures constantes de $15,18,20$, $23,25,28,30,32$ et $35^{\circ} \mathrm{C}$. Le développement larvaire et la mortalité ont été enregistrés quotidiennement. Les expériences ont été répétées avec des plaques (contenant 10-96 oufs par plaque), tous les $3 \mathrm{j}$, pendant 6 sem. Des œufs d'âge connu ont été obtenus en enlevant toutes les cellules des ruches $24 \mathrm{~h}$ avant le prélèvement des échantillons. Les cellules contenant des œufs de moins de $24 \mathrm{~h}$ ont été placées dans des plaques de culture de tissus, et maintenues à température constante comme décrit précédemment. 
Le nombre de jours nécessaires à l'achèvement du développement pour chaque stade immature (œuf, $1^{\mathrm{er}}, 2^{\mathrm{e}}, 3^{\mathrm{e}}$ et $4^{\mathrm{e}}$ stades larvaires) a été déterminé pour chaque lot, et rassemblé dans des distributions de fréquences pour chaque température constante. La procédure de Wagner et al (1984a) a été utilisée pour constituer une distribution des temps de développement, par construction de distribution de probabilités cumulées. Une fonction cumulative de Weibull a été adaptée aux temps de développement normalisés pour les stades larvaires. Des estimations de temps de développement moyen ont été réalisées à partir d'une interpolation linéaire de la distribution cumulée pour chaque température.

L'utilisation de plaques de culture de tissus couvertes pour maintenir des cellules isolées de mégachiles, apporte une protection adéquate contre la dessication, même à haute température. La survie des œufs et des stades larvaires a été généralement plus basse à 15 et à $18{ }^{\circ} \mathrm{C}$ (de $18,3 \%$ pour le $4^{\mathrm{e}}$ stade à $61 \%$ pour le $2^{\mathrm{e}}$ stade à $15^{\circ} \mathrm{C}$, et de $55,5 \%$ pour le stade œuf, à $89,6 \%$ pour le $1^{\text {er }}$ stade à $18^{\circ} \mathrm{C}$ ) (tableau I). La survie a été plus élevée de 20 à $30^{\circ} \mathrm{C}$, et des hautes températures, de $32{ }^{\circ} \mathrm{C}$ ou plus, ne causent pas davantage de mortalité des stades individuels. Quand les données ont été regroupées pour tous les stades, la survie globale de l'œuf au $4^{\mathrm{e}}$ stade s'est étalée de 1,4\% à $15^{\circ} \mathrm{C}$ jusqu'à $91 \%$ à $25^{\circ} \mathrm{C}$. La survie globale à $35{ }^{\circ} \mathrm{C}$ a été de $76,8 \%$. Ces résultats sont en accord avec les études précédentes, qui ont généralement rapporté une forte mortalité des stades immatures à basse température $\left(14\right.$ à $\left.16^{\circ} \mathrm{C}\right)$, et une survie élevée (plus de $85 \%$ ) à haute température $\left(30^{\circ} \mathrm{C}\right)$ (Bitner, 1976; Taséi et Masure, 1978; Undurraga, 1978; Tepedino et Parker, 1986).

Le taux de développement s'est accru avec l'accroissement de température, de
15 à $35^{\circ} \mathrm{C}$ pour les œufs et le $1^{\text {er stade }}$ larvaire, alors que pour les $2^{e}, 3^{e}$ et $4^{e}$ stades larvaires, le taux de développement augmente avec la température, de 15 à $30^{\circ} \mathrm{C}$, et ensuite décroît, de 32 à $35^{\circ} \mathrm{C}$ (tableau (I). Le temps de développement pour les stades combinés était respectivement de $23,5,14,5,11,6$ et 8,3 j à 20,23 , 25 et $30^{\circ} \mathrm{C}$.

La distribution des temps de développement a été déterminée pour tous les stades (fig 1).

La température influence grandement la fréquence relative des temps de développement pour les stades larvaires, avec une plus grande variation à basse température, de 15 à $20^{\circ} \mathrm{C}$. Des distributions cumulatives des temps de développement normalisés ont été déterminées pour les stades larvaires avec une distribution indépendante de la température (fig 2). Les paramètres pour l'adaptation de la fonction de Weibull sont donnés dans le tableau III.

Les résultats présentés dans cet article devraient être utiles pour l'estimation de la survie en fonction de la température et du développement des stades immatures de la mégachile. La distribution des données pour les temps de développement à différentes températures constantes sera utile pour la construction de modèles tenant compte de l'âge, qui nécessitent d'incorporer la variabilité inhérente afin d'augmenter la fiabilité de la simulation des populations naturelles.

\section{Megachile rotundata / développement / mortalité / température}

Zusammenfassung - Temperatur-
abhängige Entwicklung und Überleben
unreifer Stadien der Luzerne-
Blattschneiderbiene, Megachile rotun-
data (Hymenoptera: Megachilidae). Die
Luzerne-Blattschneidebiene Megachile ro-


tundata ist der wichtigste Bestäuber der Luzerne, Medicago sativa, in den nordwestlichen Vereinigten Staaten und Kanada. Wir haben die Populationdynamik von $M$ rotundata mit dem Ziel untersucht, Simulationsmodelle der Bienenproduktion und Luzernebestäubung zu entwerfen (Richards et al, 1987). In diesem Artikel berichten wir über die mittlere Rate und Verteilung der Entwicklung der verschiedenen Lebensstadien der LuzerneBlattschneiderbiene. Außerdem wurde die Anpassung der Daten an eine Standardverteilung zur Entwerfung von Modellen der Entwicklungszeiten berechnet. Im Labor wurde der Einfluß einer konstanten Temperatur auf Entwicklung und Überleben bestimmt. Zellen der LuzerneBlattschneiderbiene wurden aus im Feld aufgestellten Brutstöcken entnommen. Die Zelldeckel wurden zur Erleichterung der Untersuchung entfernt und alle Zellen, die ein lebensfähiges Ei (unbekannten Alters) enthielten, zur weiteren Untersuchung behalten. Die Unterbringung der Zellen erfolgte in Behältern, wie sie für Zellkulturen üblich sind und bei konstanten Temperaturen von $15,18,20,23,25,28,30,32$ und $35^{\circ} \mathrm{C}$ aufbewahrt. Larvenentwicklung und Mortalität wurden täglich registriert. Die Experimente wurden durch gleichartige Platten mit Zellen (10-96 Eier) 6 Wochen hindurch alle 3 Tage wiederholt. Eier bekannten Alters erhielten wir dadurch, daß wir von einer Sektion des Brutstockes alle Zellen 24 Stunden vor Probenentnahme entfernten. Zellen mit Eiern von einem Alter unter 24 Stunden wurden wie oben beschrieben in Zellkulturplatten bei konstanten Temperaturen gehalten. Das Ausschlüpfen wurde täglich registriert. Die Anzahl der Tage bis zum Abschluß der Entwicklung wurde für jedes unreife Stadium ( $\mathrm{Ei}$, erstes, zweites, drittes und viertes Larvenstadium) bei jedem Versuchsansatz bestimmt und daraus die Häufigkeitsverteilungen bei jeder Temperaturstufe berech- net. Um die Verteilung der Entwicklungszeiten durch Konstruktion kumulativer Wahrscheinlichkeitsverteilungen zu erlangen, wurde das Verfahren von Wagner et al (1984a) benutzt. Eine kumulative DreiParameter Weibull-Funktion wurde an die normalisierten Entwicklungszeiten der Larvenstadien angepaßt. Schätzungen der medianen Entwicklungszeit wurden aus der linearen Interpolation der kumulativen Verteilungen für jede Temperatur bestimmt. Zugedeckte Gewebskulturplatten für einzelne Zellen der LuzerneBlatischneiderbiene sorgten selbst bei hohen Temperaturen für ausreichenden Schutz vor Austrocknung. Die Überlebensrate von Eiern und Larvenstadien war im allgemeinen bei $15^{\circ} \mathrm{C}$ und $18^{\circ} \mathrm{C}$ niedriger ( $18.3 \%$ bei dem 4 -Larventstadium bis $61 \%$ bei dem 2 -Larvenstadium bei $15^{\circ} \mathrm{C}$ und $55.5 \%$ bei dem Eistadium bis $89.6 \%$ bei dem 1 -Stadium bei $18^{\circ} \mathrm{C}$, Tabelle I). Die Überlebensrate war bei $20-30^{\circ} \mathrm{C}$ am höchsten und hohe Temperaturen von $32^{\circ} \mathrm{C}$ und höher verursachten bei individuellen Stadien keine erhöhte Mortalität. Wurden die Daten von allen Stadien zusammengenommen, so bewegte sich die kombinierte Überlebensrate vom $\mathrm{Ei}$ bis zum 4-Stadium von $1.4 \%$ bei $15^{\circ} \mathrm{C}$ bis $91 \%$ bei $25^{\circ} \mathrm{C}$. Die kombinierte Überlebensrate bei $25^{\circ} \mathrm{C}$ betrug $76.8^{\circ} \mathrm{C}$. Diese Information steht in guter Übereinstimmung mit den Resultaten früherer Studien, die im allgemeinen eine hohe Mortalität unreifer Stadien bei niedrigen Temperaturen $\left(14-16^{\circ} \mathrm{C}\right)$ aber eine gute Überlebensfähigkeit (über $86 \%$ ) bei hohen Temperaturen ergaben $\left(30^{\circ} \mathrm{C}\right)$ (Bitner, 1976; Tasei und Masure, 1978; Undurage, 1978; Terpedino und Parker, 1986). Die Entwicklungsrate stieg beim $\mathrm{Ei}$ und dem 1-Stadium mit steigender Temperatur von $15^{\circ} \mathrm{C}$ bis $35^{\circ} \mathrm{C}$, aber beim $2-$, 3und 4-Larvenstadium stieg die Entwicklungsrate im allgemeinen nur von 15 bis $30^{\circ} \mathrm{C}$, um dann von 32 bis $35^{\circ} \mathrm{C}$ wieder abzufallen (Tab II). Die kombinierte Entwick- 
lungszeit für alle Stadien betrug 23.5, 14.5, 11.6 und 8.3 Tage bei einer Temperatur von $20,23,25$ und $30^{\circ} \mathrm{C}$. Für alle Stadien wurde die Verteilung der Entwicklungszeiten bestimmt (Abb 1). Die Temperatur beeinflußte in hohem Maße die relative Häufigkeit der Entwicklungszeiten, mit höherer Schwankungsbreite bei niedrigen Temperaturen von $15-20^{\circ} \mathrm{C}$. Zusammen mit einer einzigen temperaturunabhängigen Verteilung wurden für die Larvenstadien kumulative Verteilungen der normalisierten Entwicklungszeiten bestimmt (Abb 2). Die Parameter für die Übereinstimmung der Weibull--Funktion mit den einzelnen Kurven werden in Tabelle III gegeben. Die Informationen in dieser Arbeit soliten bei der Schätzung temperaturabhängigen Überlebens und der Entwicklung von unreifen Stadien der Luzerne-Blattschneiderbiene nützlicher sein. Die Daten über die Verteilung der Entwicklungszeiten bei verschiedenen konstanten Temperaturen werden bei der Konstruktion altersabhängiger Modelle nützlich sein, wobei die angeborene Variabilität für die Simulierung von Feldpopulationen berücksichtigt werden muß.

\section{Megachile rotundata / Larvenentwick- lung / Temperatur / Mortalität}

\section{REFERENCES}

Arnold CY (1959) The determination and significance of the base temperature in a linear heat unit system. Proc Am Hortic Sci 74, 430-445

Bitner RM (1976) Ecological management of the alfalfa leafcutter bee, Megachile pacifica (Panzer), with emphasis on diapause induction. Ph D dissertation, Utah State University, Logan, UT

Campbell A, Fraser BD, Gilbert N, Gutierrez AP, Mackauer M (1974) Temperature requirements of some aphids and their parasites. $J$ App/Biol 11, 431-438

Carruthers RI, Whitfield GH, Tummala RL,
Haynes DL (1986) A systems approach to research and simulation of insect pest dynamics in the onion agro-ecosystem. Ecol Model 33, 101-121

Curry GL, Feldman RM, Sharpe PJH (1978a) Foundations of stochastic development. $\checkmark$ Theor Biol 74, 397-410

Curry GL, Feldman RM, Smith KC (1978b) A stochastic model of a temperature-dependent population. $J$ Theor Biol 13, 197-213

Helwig JT, Council KA, eds (1979) SAS User's Guide. SAS Institute, Raleigh, NC, 1979 edn

Messenger PS (1959) Bioclimatic studies with insects. Annu Rev Entomol 4, 183-206

Régnière $J$ (1984) A method of describing and using variability in development rates for the simulation of insect phenology. Can Entomol 115, 1371-1382

Régnière $J$ (1987) Temperature-dependent development of eggs and larvae of Choristoneura fumiferana (Clem) (Lepidoptera: Torticidae) and simulation of its seasonal history. Can Entomol 119, 717-728

Richards KW (1984) Alfalfa Leafcutter Bee Management in Western Canada. Agric Can Publ 1495 (revised), Research Branch, Ottawa, 56 $\mathrm{pp}$

Richards KW, Whitfield GH, Schaalje GB (1987) Effects of temperature and duration of winter storage on survival and period of emergence for the alfalfa leafcutter bee (Hymenoptera: Megachilidae). J Kansas Entomol Soc 60 , 70-76

Richards KW, Whitfield GH (1988) Emergence and survival of leafcutter bees, Megachile rotundata, held at constant incubation temperatures (Hymenoptera: Megachilidae). J Apic Res 27, 197-204

Schaalje GB, van der Vaart HR (1989) Relationships among recent models for insect population dynamics with variable rates of development. J Math Biol 27, 399-428

Sharpe PJH, Curry GL, De Michele DW, Cole $\mathrm{CL}$ (1977) Distribution model of organisms development times. J Theor Biol 66, 21-38

Taséi JN, Masure MM (1978) Sur quelques facteurs influençant le développement de Megachile pacifica Panz (Hymenoptera: Megachilidae). Apidologie 9, 273-290

Tepedino VJ, Parker FD (1986) Effect of rearing 
temperature on mortality, second-generation emergence, and size of adult in Megachile rotundata (Hymenoptera: Megachilidae). $J$ Econ Entomol 79, 974-977

Undurraga JMO (1978) Effects of temperature and other abiotic and biotic factors on development and survival of the immature stages of the alfalfa leafcutting bee, Megachile pacifica (Panzer) (= rotundata (F)) (Hymenoptera: Megachilidae). $\mathrm{Ph} D$ thesis, Oregon State University, OR, 233 pp

Wagner TL, Wu H, Sharpe PJH, Coulson RD (1984a) Modelling distributions of insect development time: a literature review and application of Weibull function. Ann Entomol Soc Am 77, 208-225

Wagner TL, Wu H, Sharpe PJH, Schoolfield RM, Coulson RD (1984d) Modeling insect development rates: a literature review and application of a biophysical model. Ann Entomol Soc Am 77, 208-225

Whitfield GH, Richards KW, Kveder TM (1987) Number of instars of larvae of the alfalfa leafcutter bee, Megachile rotundata (F) (Hyme- 